[Frontiers in Bioscience, Elite, 8, 412-426, June 1, 2016]

\title{
Towards understanding the genetics of Autism
}

\author{
Harshita Shailesh ${ }^{1}$, Ishita Gupta ${ }^{2}$, Said Sif ${ }^{1}$, Allal Ouhtit ${ }^{1}$ \\ ${ }^{1}$ Department of Biological and Environmental Sciences, College of Arts \& Sciences, Qatar University, Qatar, \\ ${ }^{2}$ Department of Genetics, College of Medicine and Health Sciences, Sultan Qaboos University, PO Box 35, \\ PC 123, Al Khoud, Sultanate of Oman
}

\section{TABLE OF CONTENTS}

\section{Abstract}

2. Introduction

3. Genetics of Autism

3.1. Candidate gene studies

3.2. Association studies

3.3. Genome-wide linkage studies in ASD

3.4. Copy number variants (CNVs) and de novo single nucleotide variants (SNVs)

3.5. Autism and epigenetics

4. Current treatment strategies of ASDs

5. Conclusion

6. References

\section{ABSTRACT}

Autism spectrum disorder (ASD) includes a group of neurodevelopmental disorders that affect communication skills, social interaction and intellectual ability. Despite evidence suggesting a strong genetic link with $A S D$, the genetic determinant remains unclear. Early studies focusing on candidate genes have shown that several genes associated with neuronal synaptic function are involved in development of ASD. Linkage studies have identified several single nucleotide polymorphisms (SNPs) associated with ASD, and genome-wide association studies have implicated several loci, but failed to recognize a single specific locus with strong significance, indicating heterogeneity in ASD genetic determinants. Detection of de novo copy number variations and single nucleotide variants in several ASD probands has confirmed the genetic heterogeneity of the disease. More interestingly, next generation sequencing approaches have recently identified novel candidate genes and several point mutations in sporadic ASDs, thus increasing our knowledge of ASD etiology. The current review summarizes the findings of recent studies using genetic and genomic approaches to understand the underlying molecular mechanisms of ASD.

\section{INTRODUCTION}

Autism spectrum disorder is a group of heterogeneous disorders that usually develop during childhood, characterized by a wide range of symptoms, such as difficulties in communication and social interaction, restricted and repetitive behavior. ASDs often exhibit atypical behaviors such as hyperactivity, attention deficiency, aggressiveness, impulsive actions, and tendency to self-injuring and tantrums. Some ASD individuals are hypersensitive to normal level of light, pain, sound, smell and touch; however, some ASD patients develop normal and even advanced skills in specific areas (1). Moreover, ASD is comorbid with other conditions such as epilepsy, gastrointestinal disease and immune deficiency (2).

The word "Autism" was first coined in 1911 by German psychiatrist Eugen Bleuler to describe the severe symptoms of schizophrenia (3). Later in 1943, Leo Kanner, an American professor of childhood psychiatry, redefined autism as a disorder of mental retardation associated with innate inability to establish effective social contact and obsessiveness with specific actions (4). In the same period, another scientist Hans Asperger also observed similar but milder symptoms in several children and referred to the disorder as autistic psychopathy (5), which was later defined as Asperger's syndrome, a subtype of autism spectrum disorder. Infantile autism was included in the Diagnostic and Statistical Manual of mental disorder (DSM-III) in 1980 for the first time (6), and ever since, its periodic revision has increased the number of autism probands. DSM-IV consideres autism as a group of similar disorders composed of Autistic disorder, Asperger syndrome, Rett syndrome, Childhood Disintegrative Disorder (CDD) and Pervasive Developmental DisorderNot Otherwise Specified (PDD-NOS) (7).

Autistic disorder has an early onset, before the age of 3 years, with severe impairment in social interaction, 
communication, restricted behavior and repetitiveness. In stark contrast, Asperger syndrome children show relatively milder symptoms with improved language skills, but exhibit lonely behavior (8). Rett syndrome is mostly confined to female children, who show normal postnatal development, however, clinical symptoms such as motor and respiratory problems, social unresponsiveness, frequent seizures and delayed development start to appear at later stages (9). CDD patients show normal development up to age 3 , followed by deterioration of language skills, social function and motor skills (10). PDD-NOS children have heterogeneous symptoms of both autistic disorder and Asperger's syndrome, but improved social interaction skills and thinking capability (11). The latest edition of the Diagnostic and Statistical Manual (DSM-V) has combined all of these subgroups (excluding Rett Syndrome) into a single group referred to as autism spectrum disorder (ASD) (12).

ASD is associated with altered brain function leading to abnormal behavioral phenotype. Several studies have reported defective early brain development in ASD probands due to abnormal neural growth corresponding to age, such as increased volume of white matter and grey matter (13), increased size and number of neuronal cells in prefrontal cortex (14), small cerebellar vermis area (15), structural differences in the grey matter (16) and reduced cortical thickness (17). A recent study using the functional connectivity MRI technique has identified local functional over connections in the posterior brain of diseased individuals, indicating a role of altered neuronal communication in ASD (18). Collectively, these reports indicate that several anatomical and physiological alterations of the brain play a crucial role in the onset of ASD.

Genetics, environment and gene-environmental interactions play a vital role in the onset of abnormal physiology and anatomical defects in the brain. Extensive evidence indicates that the brain of autistic patients is subjected to several genetic and environmental influences, which in turn lead to abnormal development and functioning of the brain $(19,20)$. Early conventional genetic analyses such as candidate gene studies (21), linkage studies (22), cytogenetic approaches (23), and recent advanced genomic approaches such as genomewide association studies (24), exome sequencing (25), whole genome sequencing (26) and targeted sequencing by next-generation sequencing (27) have attempted to identify the genetic alterations in ASD. The current review will summarize our present understanding of the genetic infrastructures that might play a crucial role in the onset and development of ASD.

\section{GENETICS OF AUTISM}

The genetic link of ASD was discovered in the studies of twins, which indicated that monozygotic twins have $60-70 \%$ chance of disease incidence (28) and that of dizygotic twins is $0-30 \%(28,29)$. The role of the genetic makeup in ASD was further supported by another study, which indicated that siblings of affected children have an $18 \%$ risk of developing ASD compared to the normal population (30). Despite these reports showing strong genetic link, ASDs show heterogeneity in clinical symptoms and genetic architecture. Currently, researchers are focusing on deciphering the various genetic variations, which might play role in the onset of ASD.

ASD has higher prevalence in male children compared to female (31). Although several hypotheses have been proposed to explain the cause of sex difference in ASD incidence, none of them were able to provide significant evidence. One of the best fitting hypotheses, supported by clinical studies, suggests that in males, exposure of high levels of secreted testosterone during early gestation results in cognitive hyper-masculinization of the brain during early development, which triggers onset of the autistic syndrome (32-34).

\subsection{Candidate gene studies}

Candidate gene studies aim to investigate the gene variant in affected individuals, which could play a vital role in disease onset (35). Researchers have focused on identifying potential autism-causing candidate genes that are crucial for brain development, synapsis formation, and neurotransmission. Mutation in brain developmental pathway genes such as WNT-2, which is involved in neuronal proliferative signaling, has been observed in several ASD individuals, indicating a potential role of discrete genes in disease onset (36). Genes involved in establishing neuronal connectivity during brain development such as RELN, which has shown polymorphism in some ASD patients, has been identified as a potential candidate gene (37). Moreover, genes involved in neurotransmission such as serotonin $2 \mathrm{~A}$ receptor (HTR2A) (38) and serotonin transporter gene (SLC6A4) have also been identified as ASD candidate genes (39). Variation in genes coding for the hypothalamic hormonal pathway such as OXTR, which is considered an ASD candidate gene, has been found in ASD probands $(40,41)$. In addition, a recent study involving Chinese ASD patients showed that the schizophrenia candidate gene, CACNAIC (calcium channel, voltage-dependent, $\mathrm{L}$ type, alpha $1 \mathrm{C}$ subunit), could be a potential ASD candidate gene (42). Taken together, these candidate gene studies indicate that polygenic inheritance is prevalent in ASD.

\subsection{Association studies and linkage studies}

Association studies involving case-control groups have led to the discovery of several novel genetic loci involved in ASD development. Massive parallel sequencing of several ASD candidate genes in a large case-control cohort revealed accumulation of novel 
rare variants of genes involved in neuron excitation and neurotransmission such as CACNA2D1, KCNH7 and NRXN1 in affected individuals. Interestingly, the study indicated the presence of rare de novo single nucleotide variation leading to premature stop codon in the RNA binding gene, RBFOX1, which regulates expression of genes involved in neuronal excitation and cytoskeleton organization (43). A separate ASD association study in the Japanese population has shown two novel polymorphisms in the pre-B cell growth gene, CD157/bone marrow stromal cell antigen-1 (BST-1), highlighting the role of BST-1 polymorphism in disease susceptibility (44). On the other hand, linkage studies using large families have identified novel variations in some genes involved in brain function. A study using Italian families with affected individuals showed significant linkage of human leucocyte antigen (HLA) gene polymorphism in ASD individuals (45). Furthermore, another study involving 385 simplex and 20 multiplex Italian families identified novel variation of the Glyoxalase 1 (GLO1) gene in ASD individuals. The study also reported reduced activity of defective Glyoxalase I enzyme and accumulation of advanced glycation end products (AGES) in frozen brain samples of dead ASD individuals (46). These findings indicate that conventional genetic approaches including association and linkage studies have helped to identify novel genes that could play role in ASD development.

\subsection{Genome-wide linkage studies in ASD}

The findings of the Human Genome Project paved the way for identifying novel genetic markers for various neurological disorders. Moreover, molecular genetic tools such as array comparative genomic hybridization $(\mathrm{aCGH})$, next generation sequencing (NGS), and whole exome sequencing (WES) have also increased knowledge about genetic etiology of several disorders such as ASD. Thus, all of these recent genomic approaches have shed light on the genetic makeup and etiology of ASD, and researchers continue to make progress in identifying novel potential ASD genetic markers.

Genome-wide linkage studies have identified many novel loci present in coding and non-coding regions of affected $A S D$ individuals. Early studies of whole genome scanning using microsatellite markers have detected several loci linked to ASD. International Molecular Genetic Study of Autism Consortium (IMGSAC) identified linkage of novel loci on chromosome 7 and 16 in ASD individuals (47). Furthermore, the Paris Autism Research Sibpair Study identified novel potential markers on different chromosomes including 2, 4, 5, 6, $7,10,15,16,18,19$, and $X$ in ASD individuals from 51 multiplex families (48). An autism sib-pair study of 110 multiplex families using a high-throughput array of 335 microsatellite markers indicated significant linkage of loci located on chromosomes 5 and 8 (49). In light of the lack of consistency among these reports, it is reasonable to conclude that there is a great genetic heterogeneity in ASD. However, it should be noted that these studies had major drawbacks such as small sample size, lack of replication, and population heterogeneity, which might have contributed to variation.

Genome-wide association studies using millions of single nucleotide polymorphism (SNP) markers have gained great success in identifying several new polymorphisms in ASD. The Autism genome project used genome-wide analysis of $10 \mathrm{~K}$ SNP microarrays in 1,400 families and identified linkage of a novel region on chromosome 11p12-p13 with ASD (50). Another study by John Hopkins University using 50K SNP microarray identified two novel genome-wide association loci on chromosomes $6 q 27$ and 20p13, but with low statistical significance. However, genotyping of the top results of the study in additional families indicated a SNP on chromosome $5 \mathrm{p} 15$ with significant association, which was mapped to the region spanning two neuron functional genes SEMA5A and TAS2R. The same study also demonstrated that SEMA5A is downregulated in autism patients. This evidence indicates that the locus might be the principal regulator site of gene expression (51). Moreover, SEMA5A can be a potential ASD candidate gene since it is an axonal guidance molecule, which regulates neuron growth (52). A study genotyped large cohort of ASD families identified six SNPs in a region spanning cadherin 9 (CAD9) and cadherin 10 (CAD10), indicating a role of neuronal adhesion molecules in ASD pathogenesis (53). Genomic approaches to study the parental origin of linked SNPs indicated a strong linkage of SNPs in chromosomes 4, 15 and 20, inherited from paternal side. Although few maternal inherited linked regions were identified, they had low statistical significance (54), thus suggesting the pattern of inheritance from the paternal side. Taken together, genome-wide linkage studies have identified novel loci with high statistical significance and with most of the results confirmed in more than one cohort.

\subsection{Copy number variants (CNVs) and de novo single nucleotide variants (SNVs)}

Copy Number Variants (CNV) are variation in copy numbers of DNA segments larger than $1 \mathrm{~kb}$ due to chromosomal aberrations such as deletions, duplications, and insertions, accounting for heterogeneity among the normal individuals $(55,56)$. CNVs are extensively studied in mental disorders as they are found to be associated with many neuropsychiatric disorders and learning disabilities (57). Evidence indicates that de novo CNVs as well as inherited CNVs play vital role in onset of neurological disorders such as obsessive-compulsive disorder, schizophrenia and bipolar disorder (58-60).

Identification of rare de novo CNVs in ASD individuals by Sebat et al (2007) using comparative gene array hybridization $(\mathrm{CGH})$ technique was a major 
breakthrough, which answered most of the "missing heritability" in ASD (61). Rare CNVs, both de novo and inherited have been identified in many simplex and multiplex ASD families. Deletion and or duplication of chromosomal loci such as 16p11.2, 15q24 (62), $17 q 12$ (63), 7q11.23, 16p13.2 (64), and also some genes including SHANK3, NEUREXIN1, NEUROLIGIN4 $(62,65)$, CONTACTIN4, UBE3A, PARK2, RFWD, FBXO40 (65), CADHERIN13 (64) and CONTACTIN6 (66) have been reported in many ASD cases. A recent study has shown CNVs in GABAergic signaling pathway genes coding for GABA receptor DBI, GABA receptor-associated protein GABARAPL1, and post-synaptic GABA transporter protein SLC6A11 (67). Whole exome sequencing of ASDs has identified multiple de novo indels, which result in loss of the epigenetic regulator gene, Lysine (K)-specific methyltransferase 2E (KMT2E) and RIMS1 gene, which regulates synaptic vesicle release (68). A recent study in Finnish case-control data sets identified de novo CNVs in genes, which are involved in neuroactive ligand-receptor interaction pathways, calcium signaling pathways, and metabolic pathways such as BDKRB1, BDKRB2, AP2M1, SPTA1, PTH1R, CYP2E1, PLCD3, F2RL1, UQCRC2, LILRB3, RPS9, and COL11A2 (69). Although, several de novo and inherited CNVs have been detected in various ASD cases, their causal role has yet to be established. Functional study of recurrent CNVs in animal models will help to identify their actual role in ASD onset.

Single nucleotide variance (SNVs), due to de novo point mutation, refers to a single nucleotide change, especially within the coding region of a gene, resulting in silent mutations, missense mutations, or nonsense mutations, and are frequently reported in ASD $(70,71)$. Whole exome sequencing of ASD individuals identified several disruptive mutations in brain-expressed genes (72). SNVs leading to de novo loss of function of genes involved in synaptic functions, histone-modification and chromatin remodeling have been detected in ASD (73). Sequencing the exons and exon -intron boundaries of Glycine receptor alpha 2 (GLRA2) in 400 males from the Paris Autism Research International study (PARIS) has revealed de novo missense mutations in the gene leading to loss of function. Furthermore, functional analysis indicated that GLRA2 plays a role in axonal branching, synaptic plasticity, cognition and memory, which are deregulated when the gene is mutated (74).

\subsection{Autism and epigenetics}

Epigenetic modifications such as promoter DNA methylation at $\mathrm{CpG}$ sequences and posttranslational modification of histones regulate gene expression. Differential methylation of promoter DNA of neurodevelopmental genes has already been reported, indicating the role of epigenetic regulation in the development of neurological disorders (75). Prevalence of significant differences in clinical manifestations of monozygotic twins, despite similarity of copy number variations among these ASD twins, indicate the role of epigenetics in ASD development (76). Several ASD candidate genes are involved in chromatin structure regulation, indicating the role of epigenetic alterations in disease development. Mutations in SWI/SNF-based chromatin remodeling complexes such as ADNP and ARID1B, and genes coding for histone demethylases such as JARID1C/SMCX, have been reported in ASD (77-79). Multiple de novo indels in the exons of the chromatin regulator gene, Lysine (K)-specific methyltransferase $2 \mathrm{E}$ (KMT2E), are reported in many ASD cases (80). Elevated levels of microRNAs including miR-142-5p, miR-142-3p, miR-144-3p, miR-21 and miR-451a have been reported in the brains of autism individuals, of which miR-21 and miR-451a have binding region at 3'UTR of oxytocin receptor gene transcript. Gene expression analysis and western blotting studies indicated that mRNA level of OXTR is increased in these individuals, however OXTR protein level is kept low, due to increased miR-21 level, (81). Oxytocin receptor is involved in an important pathway that regulates social behavior and found to be deregulated in ASD (82).

Environmental toxins have an adverse impact on DNA methylation and other epigenetic modifications, altering many developmental processes, including neurodevelopment (83). Prenatal exposure to various environmental conditions has been found to increase ASD risk in children (84). Increased prevalence of ASD has been observed in children residing in close proximity to industries emitting air-pollutants such as arsenic, which changes global DNA methylation, histone acetylation and methylation $(85,86)$. High levels of heavy metals as well as minerals including sulfur, sodium, magnesium, potassium, zinc, and iron, and low levels of calcium and copper are present in the hair of children with autism (87). Autism is also associated with reduced levels of both antioxidant resources and methylation capacity along with high levels of mercury in hair (88). Maternal consumption of folic acid, a potential methyl donor to DNA methylation enzymes, and S-adenosylmethionine (SAM) during pregnancy is a known protective mechanism against ASD (89).

\section{CURRENT TREATMENT STRATEGIES OF ASD}

The current treatment strategies for ASD aim to reduce the abnormal behavioral symptoms. Antipsychotics and antianxiety drugs along with adjuvant treatment strategies such as behavioral therapy, special educational approaches, speech therapy and cognitive therapy are generally used to improve the symptoms associated with ASD $(90,91)$. Moreover, strong evidence suggests that incorporation of an adequate diet plan helps to overcome several co-morbidities associated with ASD (92). Dietary elimination of casein and gluten shows 
improved disease status than normal diet consuming ASD individuals (93). Dietary supplementation of deficit nutrients in ASDs such as omega-3 fatty acids, probiotics, vitamins, folic acid, and several minerals have been shown to be beneficial in reducing some autism symptoms (94). Also, in relation to diet, there is a necessity for awareness to ensure sufficient intake of nutrients including vitamin B12, folate and foodstuff containing DHA, to further reduce or reverse any adverse effects of nutrient deficiency (95).

\section{CONCLUSIONS AND FUTURE PROSPECTIVE}

Identifying the genetic etiology of ASD was challenging 50 years ago. But, recent advances in genetic and genomic techniques including microarray, $\mathrm{CGH}$ array, whole exome sequencing and next generation sequencing have lead to the discovery of many novel de novo and inherited chromosomal aberrations, SNPs, CNVs and epigenetic modifications associated with ASD. Genome-wide association studies have indicated that commonly inherited variations have higher potential to increase the disease risk (96); however, the individual effect of each variant is very low (97). Although, several rare inherited mutations have been reported in some ASD probands, their effect in imposing ASD risk still lies nascent, except bi-allelic alterations in neuronal protein coding gene, which contributes significantly in disease onset (98). Taken together, recent investigations redefine ASD as a heterogeneous disorder originating from various genetic patterns such as inherited genetic loci from parents to the affected child, de novo variations due to germ line mutations, and epigenetic modifications.

Identification of novel genetic markers has increased knowledge regarding genetic architecture of ASD; however, wide heterogeneity of these variations has limited their application as diagnostic markers. Combining genetic studies with functional analyses serves as a powerful tool to identify genetic architecture of ASD, while explaining the molecular mechanism of ASD onset. Furthermore, these identified genetic markers may represent potential diagnostic criteria for prenatal diagnosis as well as in newborn babies. Identifying novel markers may pave the way towards targeted treatment strategies, prognosis, and better monitoring of disease recurrence post-treatment. Identification of novel predisposition markers may also aid in delay the onset of ASD. Finding common variations among autism probands helps to subtype the disease population and allows prescribing specific treatment strategies. Early detection of ASD helps therapists to guide and inform families about the chances of pervasiveness of the disease in next siblings (99). Increased genetic understanding of ASD has tried to answer the cause of ASD associated comorbidities. The search for de novo copy number variations has revealed CNV in genes involved in metabolic pathways, indicating the cause of metabolic alterations in ASD patients (76). Researchers continue to identify common and inherited mutations, which may play a potential role in onset and development of autism.

Gaining the immense knowledge about autism genetics has opened the path to search for novel drug treatments. For instance, discovery of oxytocin dysfunction in ASD has led to development of oxytocin as a drug treatment in ASD patients. Oxytocin therapy is considered a promising treatment in betterment of ASD symptoms such as enhanced social interactions; however, this treatment has been found to have no effect in some ASD individuals. The wide spectrum of ASD genetic heterogeneity may be one of the underlying causes for this failure (100), further emphasizing the need of personalized therapy in ASD individuals. To this end, researchers have tried to reverse the malfunctioning of several proteins in autism, and restoration of mutated synaptic protein nurexin (NRXN1- $\beta$ ) has been successful in mice. This reversal reduced the autistic behavior such as repetitive behavior, reduced social interaction in mice (101). Thus, there is great hope that through these molecular and experimental therapeutic trials, more and more corrective approaches will be unraveled which will help guide clinicians better design treatment strategies for eventual clinical trials.

\section{REFERENCES}

1. D. E. Battle: Diagnostic and Statistical Manual of Mental Disorders (DSM). CoDAS, 25(2), 191-2 (2013)

DOI: 10.1590/S2317-17822013000200017 PMid:24413388

2. J. Veenstra-VanderWeele and R. D. Blakely: Networking in autism: leveraging genetic, biomarker and model system findings in the search for new treatments. Neuropsychopharmacology: official publication of the American College of Neuropsychopharmacology, 37(1), 196-212 (2012)

DOI: 10.1038/npp.2011.185

PMid:21937981 PMCid: PMC3238072

3. C. Tillman: Dementia Praecox or the Group of Schizophrenias. Eugen Bleuler; translated by Joseph Zinkin. New York: International Universities Press, 1950. 548 pp. \$7.5.0. Science, 113(2935), 368-368 (1951)

DOI: 10.1126/science.113.2935.368-a

4. L. Kanner: Autistic disturbances of affective contact. Nervous Child, 2, 217-250 (1943) 
5. L. Tsai: Asperger's Disorder will be Back. Journal of Autism and Developmental Disorders, 43(12), 2914-2942 (2013)

DOI: $10.1007 / \mathrm{s} 10803-013-1839-2$

PMid:23644916

6. American Psychiatric Association. Diagnostic and statistical manual of mental disorders. $3^{\text {rd }}$ edition. Washington, DC: American Psychiatric Publishing; 1980.

7. F.R.Volkmar, A. Klin, B. Siegel, P. Szatmari, C. Lord, M. Campbell: Field trial for autistic disorder in DSM-IV. American $J$ ournal of Psychiatry. 151(9), 1361-1367 (1994)

DOI: 10.1176/ajp.151.9.1361

PMid:8067493

8. J. H. Miles: Autism spectrum disorders(mdash) A genetics review. Genet Med, 13(4), 278-294 (2011)

DOI: 10.1097/GIM.0b013e3181ff67ba

PMid:21358411

9. L. Pozzo-Miller, S. Pati, and A. K. Percy: Rett Syndrome: Reaching for Clinical Trials. Neurotherapeutics, 12(3), 631-640 (2015)

DOI: $10.1007 / \mathrm{s} 13311-015-0353-y$

PMid:25861995

10. S. H. Charan: Childhood disintegrative disorder. Journal of Pediatric Neurosciences, 7(1), 55-57 (2012)

DOI: $10.4103 / 1817-1745.97627$

PMid:22837782 PMCid: PMC3401658

11. D. R. Walker, A. Thompson, L. Zwaigenbaum, J. Goldberg, S. E. Bryson, W. J. Mahoney, C. P.Strawbridge and P. Szatmari: Specifying PDD-NOS: a comparison of PDD-NOS, Asperger syndrome, and autism. $J A m$ Acad Child Adolesc Psychiatry, 43(2), 172-180 (2004)

DOI: 10.1097/00004583-200402000-00012

PMid:14726723

12. J. F. Rodríguez-Testal, S.-C. Cristina and S. Perona-Garcelán: From DSM-IV-TR to DSM5: Analysis of some changes. International Journal of Clinical and Health Psychology, 14(3), 221-231 (2014)

DOI: $10.1016 / j . j$.jchp.2014.05.002

13. Z. Xiao, T. Qiu, X. Ke, X. Xiao, T. Xiao, F. Liang, B. Zou, H. Huang, H. Fang, K. Chu, J. Zhang and Y. Liu: Autism Spectrum Disorder as Early Neurodevelopmental Disorder: Evidence from the Brain Imaging Abnormalities in
2-3 Years Old Toddlers. Journal of Autism and Developmental Disorders, 44(7), 1633-1640 (2014)

DOI: 10.1007/s10803-014-2033-X

PMid:24419870 PMCid: PMC4057630

14. E. Courchesne, P. R. Mouton, M. E. Calhoun, K. Semendeferi, C. Ahrens- Barbeau, M. J. Hallet, C. C. Barness and K. Pierce: Neuron number and size in prefrontal cortex of children with autism. The journal of the American medical association, 306(18), 2001-2010 (2011)

DOI: 10.1001/jama.2011.1638

PMid:22068992

15. S. J. Webb, B. F. Sparks, S. D. Friedman, D. W. Shaw, J. Giedd, G. Dawson and S. R. Dager: Cerebellar vermal volumes and behavioral correlates in children with autism spectrum disorder. Psychiatry Res, 172(1), 61-67 (2009)

DOI: 10.1016/j.pscychresns.2008.06.001

PMid:19243924 PMCid: PMC2676721

16. N. E. Foster, K. A. Doyle-Thomas, A. Tryfon, T. Ouimet, E. Anagnostou, A. C. Evans, L. Zwaigenbaum, J. P. Lerch, J. D. Lewis and K. L. Hyde: Structural Gray Matter Differences During Childhood Development in Autism Spectrum Disorder: A Multimetric Approach. Pediatr Neurol (2015)

17. J. Richter, R. Henze, K. Vomstein, B. Stieltjes, P. Parzer, J. Haffner, D. Brandeis and L. Poustka: Reduced cortical thickness and its association with social reactivity in children with autism spectrum disorder. Psychiatry Res (2015)

18. Christopher L. Keown, P. Shih, A. Nair, N. Peterson, Mark E. Mulvey and R.-A. Müller: Local Functional Overconnectivity in Posterior Brain Regions Is Associated with Symptom Severity in Autism Spectrum Disorders. Cell Reports, 5(3), 567-572 (2013)

DOI: 10.1016/j.celrep.2013.10.003

PMid:24210815

19. P. Chaste and M. Leboyer: Autism risk factors: genes, environment, and geneenvironment interactions. Dialogues in clinical neuroscience, 14(3), 281-92 (2012)

20. S. Tordjman, E. Somogyi, N. Coulon, S. Kermarrec, D. Cohen, G. Bronsard, O. Bonnot, C. Weismann-Arcache, M. Botbol, B. Lauth, V. Ginchat, P. Roubertoux, M. Barburoth, V. 
Kovess, M. M. Geoffray and J. Xavier: Gene x Environment interactions in autism spectrum disorders: role of epigenetic mechanisms. Front Psychiatry, 5, 53 (2014)

21. E. Bonora, K. S. Beyer, J. A. Lamb, J. R. Parr, S. M. Klauck, A. Benner, M. Paolucci, A. Abbott, I. Ragoussis, A. Poustka, A. J. Bailey and A. P. Monaco: Analysis of reelin as a candidate gene for autism. Mol Psychiatry, 8(10), 885-92 (2003)

DOI: $10.1038 /$ sj.mp.4001310

PMid:14515139

22. P. Szatmari, A. D. Paterson, L. Zwaigenbaum, W. Roberts, J. Brian, X. Q. Liu, J. B. Vincent, J. L. Skaug, A. P. Thompson, L. Senman, L. Feuk, C. Qian, S. E. Bryson, M. B. Jones, C. R. Marshall, S. W. Scherer, V. J. Vieland, C. Bartlett, L. V. Mangin, R. Goedken, A. Segre, M. A. Pericak-Vance, M. L. Cuccaro, J. R. Gilbert, H. H. Wright, R. K. Abramson, C. Betancur, T. Bourgeron, C. Gillberg, M. Leboyer, J. D. Buxbaum, K. L. Davis, E. Hollander, J. M. Silverman, J. Hallmayer, L. Lotspeich, J. S. Sutcliffe, J. L. Haines, S. E. Folstein, J. Piven, T. H. Wassink, V. Sheffield, D. H. Geschwind, M. Bucan, W. T. Brown, R. M. Cantor, J. N. Constantino, T. C. Gilliam, M. Herbert, C. Lajonchere, D. H. Ledbetter, C. Lese-Martin, J. Miller, S. Nelson, C. A. Samango-Sprouse, S. Spence, M. State, R. E. Tanzi, H. Coon, G. Dawson, B. Devlin, A. Estes, P. Flodman, L. Klei, W. M. McMahon, N. Minshew, J. Munson, E. Korvatska, P. M. Rodier, G. D. Schellenberg, M. Smith, M. A. Spence, C. Stodgell, P. G. Tepper, E. M. Wijsman, C. E. Yu, B. Roge, C. Mantoulan, K. Wittemeyer, A. Poustka, B. Felder, S. M. Klauck, C. Schuster, F. Poustka, S. Bolte, S. Feineis-Matthews, E. Herbrecht, G. Schmotzer, J. Tsiantis, K. Papanikolaou, E. Maestrini, E. Bacchelli, F. Blasi, S. Carone, C. Toma, H. Van Engeland, M. de Jonge, C. Kemner, F. Koop, M. Langemeijer, C. Hijmans, W. G. Staal, G. Baird, P. F. Bolton, M. L. Rutter, E. Weisblatt, J. Green, C. Aldred, J. A. Wilkinson, A. Pickles, A. Le Couteur, T. Berney, H. McConachie, A. J. Bailey, K. Francis, G. Honeyman, A. Hutchinson, J. R. Parr, S. Wallace, A. P. Monaco, G. Barnby, K. Kobayashi, J. A. Lamb, I. Sousa, N. Sykes, E. H. Cook, S. J. Guter, B. L. Leventhal, J. Salt, C. Lord, C. Corsello, V. Hus, D. E.
Weeks, F. Volkmar, M. Tauber, E. Fombonne, A. Shih and K. J. Meyer: Mapping autism risk loci using genetic linkage and chromosomal rearrangements. Nature genetics, 39(3), 319-28 (2007)

DOI: $10.1038 / \mathrm{ng} 1985$

PMid: 17322880

23. E. Weidmer-Mikhail, S. Sheldon and M. Ghaziuddin: Chromosomes in autism and related pervasive developmental disorders: a cytogenetic study. J Intellect Disabil Res, 42 (Pt 1), 8-12 (1998)

24. R. Anney, L. Klei, D. Pinto, R. Regan, J. Conroy, T. R. Magalhaes, C. Correia, B. S. Abrahams, N. Sykes, A. T. Pagnamenta, J. Almeida, E. Bacchelli, A. J. Bailey, G. Baird, A. Battaglia, T. Berney, N. Bolshakova, S. Bolte, P. F. Bolton, T. Bourgeron, S. Brennan, J. Brian, A. R. Carson, G. Casallo, J. Casey, S. H. Chu, L. Cochrane, C. Corsello, E. L. Crawford, A. Crossett, G. Dawson, M. de Jonge, R. Delorme, I. Drmic, E. Duketis, F. Duque, A. Estes, P. Farrar, B. A. Fernandez, S. E. Folstein, E. Fombonne, C. M. Freitag, J. Gilbert, C. Gillberg, J. T. Glessner, J. Goldberg, J. Green, S. J. Guter, H. Hakonarson, E. A. Heron, M. Hill, R. Holt, J. L. Howe, G. Hughes, V. Hus, R. Igliozzi, C. Kim, S. M. Klauck, A. Kolevzon, O. Korvatska, V. Kustanovich, C. M. Lajonchere, J. A. Lamb, M. Laskawiec, M. Leboyer, A. Le Couteur, B. L. Leventhal, A. C. Lionel, X. Q. Liu, C. Lord, L. Lotspeich, S. C. Lund, E. Maestrini, W. Mahoney, C. Mantoulan, C. R. Marshall, H. McConachie, C. J. McDougle, J. McGrath, W. M. McMahon, N. M. Melhem, A. Merikangas, O. Migita, N. J. Minshew, G. K. Mirza, J. Munson, S. F. Nelson, C. Noakes, A. Noor, G. Nygren, G. Oliveira, K. Papanikolaou, J. R. Parr, B. Parrini, T. Paton, A. Pickles, J. Piven, D. J. Posey, A. Poustka, F. Poustka, A. Prasad, J. Ragoussis, K. Renshaw, J. Rickaby, W. Roberts, K. Roeder, B. Roge, M. L. Rutter, L. J. Bierut, J. P. Rice, J. Salt, K. Sansom, D. Sato, R. Segurado, L. Senman, N. Shah, V. C. Sheffield, L. Soorya, I. Sousa, V. Stoppioni, C. Strawbridge, R. Tancredi, K. Tansey, B. Thiruvahindrapduram, A. P. Thompson, S. Thomson, A. Tryfon, J. Tsiantis, H. Van Engeland, J. B. Vincent, F. Volkmar, S. Wallace, K. Wang, Z. Wang, T. H. Wassink, K. Wing, K. Wittemeyer, S. Wood, B. L. Yaspan, D. Zurawiecki, L. Zwaigenbaum, C. Betancur, 
J. D. Buxbaum, R. M. Cantor, E. H. Cook, H. Coon, M. L. Cuccaro, L. Gallagher, D. H. Geschwind, M. Gill, J. L. Haines, J. Miller, A. P. Monaco, J. I. Nurnberger, Jr., A. D. Paterson, M. A. Pericak-Vance, G. D. Schellenberg, S. W. Scherer, J. S. Sutcliffe, P. Szatmari, A. M. Vicente, V. J. Vieland, E. M. Wijsman, B. Devlin, S. Ennis and J. Hallmayer: A genomewide scan for common alleles affecting risk for autism. Human molecular genetics, 19(20), 4072-82 (2010)

Doi:10.1.093/hmg/ddq307

25. M. G. Butler, S. K. Rafi, W. Hossain, D. A. Stephan and A. M. Manzardo: Whole exome sequencing in females with autism implicates novel and candidate genes. International journal of molecular sciences, 16(1), 1312-35 (2015)

DOI: 10.3390/ijms16011312

PMid:25574603 PMCid: PMC4307305

26. R. K. C. Yuen, B. Thiruvahindrapuram, D. Merico, S. Walker, K. Tammimies, N. Hoang, C. Chrysler, T. Nalpathamkalam, G. Pellecchia, Y. Liu, M. J. Gazzellone, L. D'Abate, E. Deneault, J. L. Howe, R. S. C. Liu, A. Thompson, M. Zarrei, M. Uddin, C. R. Marshall, R. H. Ring, L. Zwaigenbaum, P. N. Ray, R. Weksberg, M. T. Carter, B. A. Fernandez, W. Roberts, P. Szatmari and S. $W$. Scherer: Whole-genome sequencing of quartet families with autism spectrum disorder. Nat Med, 21(2), 185-191 (2015)

DOI: $10.1038 / \mathrm{nm} .3792$

PMid:25621899

27. E. Koshimizu, S. Miyatake, N. Okamoto, M. Nakashima, Y. Tsurusaki, N. Miyake, H. Saitsu and N. Matsumoto: Performance comparison of bench-top next generation sequencers using microdroplet PCR-based enrichment for targeted sequencing in patients with autism spectrum disorder. PloS one, 8(9), e74167 (2013)

DOI: 10.1371/journal.pone.0074167

PMid:24066114 PMCid: PMC3774667

28. A. Bailey, A. Le Couteur, I. Gottesman, P. Bolton, E. Simonoff, E. Yuzda and M. Rutter: Autism as a strongly genetic disorder: evidence from a British twin study. Psychol Med, 25(1), 63-77 (1995)

DOI: 10.1017/S0033291700028099

PMid:7792363
29. R. E. Rosenberg, J. K. Law, G. Yenokyan, J. McGready, W. E. Kaufmann and P. A. Law: Characteristics and concordance of autism spectrum disorders among 277 twin pairs. Arch Pediatr Adolesc Med, 163(10), 907-914 (2009)

30. S. Ozonoff, G. S. Young, A. Carter, D. Messinger, N. Yirmiya, L. Zwaigenbaum, S. Bryson, L. J. Carver, J. N. Constantino, K. Dobkins, T. Hutman, J. M. Iverson, R. Landa, S. J. Rogers, M. Sigman and W. L. Stone: Recurrence risk for autism spectrum disorders: a Baby Siblings Research Consortium study. Pediatrics, 128(3), e488-495 (2011)

DOI: 10.1542/peds.2010-2825

31. D. M. Werling and D. H. Geschwind: Sex differences in autism spectrum disorders. Current opinion in neurology, 26(2), 146-153 (2013).

DOI: 10.1097/WCO.0b013e32835ee548

PMid:23406909 PMCid: PMC4164392

32. S. Baron-Cohen: The extreme male brain theory of autism. Trends Cogn Sci, 6(6), 248-254 (2002)

DOI: 10.1016/S1364-6613(02)01904-6

33. B. Auyeung, S. Baron-Cohen, E. Ashwin, R. Knickmeyer, K. Taylor and G. Hackett: Fetal testosterone and autistic traits. Br J Psychol, 100(Pt 1), 1-22 (2009)

34. I. Hauth, Y. G. de Bruijn, W. Staal, J. K. Buitelaar and N. N. Rommelse: Testing the extreme male brain theory of autism spectrum disorder in a familial design. Autism Res, 7(4), 491-500 (2014)

DOI: 10.1002/aur.1384

PMid:24777834

35. R. Patnala, J. Clements and J. Batra: Candidate gene association studies: a comprehensive guide to useful in silico tools. BMC Genetics, 14(1), 39 (2013)

DOI: 10.1186/1471-2156-14-39

PMid:23656885 PMCid: PMC3655892

36. T. H. Wassink, J. Piven, V. J. Vieland, J. Huang, R. E. Swiderski, J. Pietila, T. Braun, G. Beck, S. E. Folstein, J. L. Haines and V. C. Sheffield: Evidence supporting WNT2 as an autism susceptibility gene. Am J Med Genet, 105(5), 406-13 (2001)

DOI: 10.1002/ajmg.1401

PMid:11449391 
37. D. A. Skaar, Y. Shao, J. L. Haines, J. E. Stenger, J. Jaworski, E. R. Martin, G. R. DeLong, J. H. Moore, J. L. McCauley, J. S. Sutcliffe, A. E. Ashley-Koch, M. L. Cuccaro, S. E. Folstein, J. R. Gilbert and M. A. Pericak-Vance: Analysis of the RELN gene as a genetic risk factor for autism. Mol Psychiatry, 10(6), 563-71 (2005)

DOI: $10.1038 /$ sj.mp.4001614

PMid:15558079

38. J. Veenstra-VanderWeele, S. J. Kim, C. Lord, R. Courchesne, N. Akshoomoff, B. L. Leventhal, E. Courchesne and E. H. Cook, Jr.: Transmission disequilibrium studies of the serotonin 5-HT2A receptor gene (HTR2A) in autism. Am J Med Genet, 114(3), 277-83 (2002)

DOI: 10.1002/ajmg.10192

PMid:11920848

39. S. J. Kim, N. Cox, R. Courchesne, C. Lord, C. Corsello, N. Akshoomoff, S. Guter, B. L. Leventhal, E. Courchesne and E. H. Cook, Jr.: Transmission disequilibrium mapping at the serotonin transporter gene (SLC6A4) region in autistic disorder. Mol Psychiatry, 7(3), 278-88 (2002)

DOI: $10.1038 /$ sj.mp.4001033

PMid:11920155

40. D. LoParo and I. D. Waldman: The oxytocin receptor gene (OXTR) is associated with autism spectrum disorder: a meta-analysis. Mol Psychiatry, 20(5), 640-646 (2015)

DOI: $10.1038 / \mathrm{mp} .2014 .77$

PMid:25092245

41. S. Wu, M. Jia, Y. Ruan, J. Liu, Y. Guo, M. Shuang, X. Gong, Y. Zhang, X. Yang and D. Zhang: Positive association of the oxytocin receptor gene (OXTR) with autism in the Chinese Han population. Biol Psychiatry, 58(1), 74-7 (2005)

DOI: 10.1016/j.biopsych.2005.03.013 PMid:15992526

42. J. Li, L. Zhao, Y. You, T. Lu, M. Jia, H. Yu, Y. Ruan, W. Yue, J. Liu, L. Lu, D. Zhang and L. Wang: Schizophrenia Related Variants in CACNA1C also Confer Risk of Autism. PLoS One, 10(7), e0133247 (2015)

DOI: 10.1371/journal.pone.0133247

PMid:26204268 PMCid: PMC4512676

43. A. J. Griswold, N. D. Dueker, D. Van Booven, J. A. Rantus, J. M. Jaworski, S. H. Slifer, M. A. Schmidt, W. Hulme, I. Konidari, P. L.
Whitehead, M. L. Cuccaro, E. R. Martin, J. L. Haines, J. R. Gilbert, J. P. Hussman and M. A. Pericak-Vance: Targeted massively parallel sequencing of autism spectrum disorderassociated genes in a case control cohort reveals rare loss-of-function risk variants. $\mathrm{Mol}$ Autism, 6, 43 (2015)

44. S. Yokoyama, N. Al Mahmuda, T. Munesue, K. Hayashi, K. Yagi, M. Yamagishi and H. Higashida: Association Study between the CD157/BST1 Gene and Autism Spectrum Disorders in a Japanese Population. Brain Sciences, 5(2), 188-200 (2015)

45. F. R. Guerini, E. Bolognesi, M. Chiappedi, A. De Silvestri, A. Ghezzo, M. Zanette, B. Rusconi, S. Manca, S. Sotgiu, C. Agliardi and M.Clerici: HLA polymorphisms in Italian children with autism spectrum disorders: Results of a family based linkage study. Journal of Neuroimmunology, 230(1-2), 135-142 (2011)

46. S. Gabriele, F. Lombardi, R. Sacco, V. Napolioni, L. Altieri, M. C. Tirindelli, C. Gregorj, C. Bravaccio, F. Rousseau and A. M. Persico: The GLO1 C332 (Ala111) allele confers autism vulnerability: family-based genetic association and functional correlates. J Psychiatr Res, 59, 108-16 (2014)

DOI: 10.1016/j.jpsychires.2014.07.021 PMid:25201284

47. A full genome screen for autism with evidence for linkage to a region on chromosome 7q. International Molecular Genetic Study of Autism Consortium. Hum Mol Genet, 7(3), 571-578. (1998)

48. A. Philippe, M. Martinez, M. Guilloud-Bataille, C. Gillberg, M. Rastam, E. Sponheim, M. Coleman, M. Zappella, H. Aschauer, L. Van Maldergem, C. Penet, J. Feingold, A. Brice and M. Leboyer: Genome-wide scan for autism susceptibility genes. Paris Autism Research International Sibpair Study. Human molecular genetics, 8(5), 805-12 (1999)

DOI: $10.1093 / \mathrm{hmg} / 8.5 .805$

PMid:10196369

49. J. Liu, D. R. Nyholt, P. Magnussen, E. Parano, P. Pavone, D. Geschwind, C. Lord, P. Iversen, J. Hoh, J. Ott and T. C. Gilliam: A genomewide screen for autism susceptibility loci. American journal of human genetics, 69(2), 327-40 (2001) 
DOI: $10.1086 / 321980$

PMid:11452361 PMCid: PMC1235325

50. Hu-Lince, D. Craig, D. W. Huentelman, M. J. and Stephan, D. A. The Autism Genome Project: goals and strategies. Am J Pharmacogenomics, 5(4), 233-246 (2005) DOI: 10.2165/00129785-200505040-00004 PMid: 16078860

51. L. A. Weiss, D. E. Arking, M. J. Daly and A. Chakravarti: A genome-wide linkage and association scan reveals novel loci for autism. Nature, 461(7265), 802-8 (2009)

DOI: $10.1038 /$ nature 08490 PMid:19812673 PMCid: PMC2772655

52. D. B. Kantor, O. Chivatakarn, K. L. Peer, S. F. Oster, M. Inatani, M. J. Hansen, J. G. Flanagan, Y. Yamaguchi, D. W. Sretavan, R. J. Giger and A. L. Kolodkin: Semaphorin $5 \mathrm{~A}$ is a bifunctional axon guidance cue regulated by heparan and chondroitin sulfate proteoglycans. Neuron, 44(6), 961-975 (2004) DOI: 10.1016/j.neuron.2004.12.002 PMid:15603739

53. K. Wang, H. Zhang, D. Ma, M. Bucan, J. T. Glessner, B. S. Abrahams, D. Salyakina, M. Imielinski, J. P. Bradfield, P. M. Sleiman, C. E. Kim, C. Hou, E. Frackelton, R. Chiavacci, N. Takahashi, T. Sakurai, E. Rappaport, C. M. Lajonchere, J. Munson, A. Estes, O. Korvatska, J. Piven, L. I. Sonnenblick, A. I. Alvarez Retuerto, E. I. Herman, H. Dong, T. Hutman, M. Sigman, S. Ozonoff, A. Klin, T. Owley, J. A. Sweeney, C. W. Brune, R. M. Cantor, R. Bernier, J. R. Gilbert, M. L. Cuccaro, W. M. McMahon, J. Miller, M. W. State, T. H. Wassink, H. Coon, S. E. Levy, R. T. Schultz, J. I. Nurnberger, J. L. Haines, J. S. Sutcliffe, E. H. Cook, N. J. Minshew, J. D. Buxbaum, G. Dawson, S. F. Grant, D. H. Geschwind, M. A. Pericak-Vance, G. D. Schellenberg and $\mathrm{H}$. Hakonarson: Common genetic variants on $5 \mathrm{p} 14.1$. associate with autism spectrum disorders. Nature, 459(7246), 528-33 (2009) DOI: 10.1038/nature07999

PMid:19404256 PMCid: PMC2943511

54. D. Fradin, K. Cheslack-Postava, C. LaddAcosta, C. Newschaffer, A. Chakravarti, D. E. Arking, A. Feinberg and M. D. Fallin: Parentof-origin effects in autism identified through genome-wide linkage analysis of 16,000 SNPs. PloS one, 5(9) (2010)
55. P. Stankiewicz and J. R. Lupski: Structural variation in the human genome and its role in disease. Annu Rev Med, 61, 437-455 (2010) DOI: 10.1146/annurev-med-100708-204735 PMid:20059347

56. J. Sebat, B. Lakshmi, J. Troge, J. Alexander, J. Young, P. Lundin, S. Maner, H. Massa, M. Walker, M. Chi, N. Navin, R. Lucito, J. Healy, J. Hicks, K. Ye, A. Reiner, T. C. Gilliam, B. Trask, N. Patterson, A. Zetterberg and M. Wigler: Large-scale copy number polymorphism in the human genome. Science, 305(5683), 525-8 (2004)

DOI: 10.1126/science.1098918

PMid:15273396

57. A. K. Merikangas, A. P. Corvin and L. Gallagher: Copy-number variants in neurodevelopmental disorders: promises and challenges. Trends Genet, 25(12), 536-544 (2009)

DOI: 10.1016/j.tig.2009.10.006

PMid:19910074

58. C. Cappi, A. G. Hounie, D. B. Mariani, J. B. Diniz, A. R. Silva, V. N. Reis, A. F. Busso, A. G. Silva, F. Fidalgo, S. R. Rogatto, E. C. Miguel, A. C. Krepischi and H. Brentani: An inherited smalll microdeletion at $15 q 13.3$ in a patient with early-onset obsessive-compulsive disorder. PLoS One, 9(10), e110198 (2014)

DOI: 10.1371/journal.pone.0110198

PMid:25303678 PMCid: PMC4193873

59. Q. Zhao, T. Li, X. Zhao, K. Huang, T. Wang, Z. Li, J. Ji, Z. Zeng, Z. Zhang, K. Li, G. Feng, D. St Clair, L. He and Y. Shi: Rare CNVs and tag SNPs at $15 q 11.2$ are associated with schizophrenia in the Han Chinese population. Schizophr Bull,39(3),712-719 (2013)

60. E. K. Green, E. Rees, J. T. Walters, K. G. Smith, L. Forty, D. Grozeva, J. L. Moran, P. Sklar, S. Ripke, K. D. Chambert, G. Genovese, S. A. McCarroll, I. Jones, L. Jones, M. J. Owen, M. C. O'Donovan, N. Craddock and G. Kirov: Copy number variation in bipolar disorder. $\mathrm{Mol}$ Psychiatry, 21(1), 89-93 (2016)

DOI: $10.1038 / \mathrm{mp} .2014 .174$

PMid:25560756

61. J. Sebat, B. Lakshmi, D. Malhotra, J. Troge, C. Lese-Martin, T. Walsh, B. Yamrom, S. Yoon, A. Krasnitz, J. Kendall, A. Leotta, D. Pai, R. Zhang, Y. H. Lee, J. Hicks, S. J. Spence, A. T. Lee, K. Puura, T. Lehtimaki, D. Ledbetter, P. K. Gregersen, J. Bregman, J. S. Sutcliffe, V. 
Jobanputra, W. Chung, D. Warburton, M. C. King, D. Skuse, D. H. Geschwind, T. C. Gilliam, K. Ye and M. Wigler: Strong association of de novo copy number mutations with autism. Science, 316(5823), 445-9 (2007)

DOI: $10.1126 /$ science. 1138659

PMid:17363630 PMCid: PMC2993504

62. C. R. Marshall, A. Noor, J. B. Vincent, A. C. Lionel, L. Feuk, J. Skaug, M. Shago, R. Moessner, D. Pinto, Y. Ren, B. Thiruvahindrapduram, A. Fiebig, S. Schreiber, J. Friedman, C. E. Ketelaars, Y. J. Vos, C. Ficicioglu, S. Kirkpatrick, R. Nicolson, L. Sloman, A. Summers, C. A. Gibbons, A. Teebi, D. Chitayat, R. Weksberg, A. Thompson, C. Vardy, V. Crosbie, S. Luscombe, R. Baatjes, L. Zwaigenbaum, W. Roberts, B. Fernandez, P. Szatmari and S. W. Scherer: Structural variation of chromosomes in autism spectrum disorder. American journal of human genetics, 82(2), 477-88 (2008)

DOI: 10.1016/j.ajhg.2007.12.009

PMid:18252227 PMCid: PMC2426913

63. D. Moreno-De-Luca, J. G. Mulle, Simons Simplex Collection Genetics Consortium, E. B. Kaminsky, S. J. Sanders, S.M. Myers, M. P. Adam, A. T. Pakula, N. J. Eisenhauer, K. Uhas, L. Weik, L. Guy, M. E. Care, C. F. Morel, C. Boni, B. A. Salbert, A. Chandrareddy, L. A. Demmer, E. W. Chow, U. Surti, S. Aradhya, D. L. Pickering, D. M. Golden, W. G. Sanger, E. Aston, A. R. Brothman, T. J. Gliem, E. C. Thorland, T. Ackley, R. lyer, S. Huang, J. C. Barber, J. A. Crolla, S.T. Warren, C. L. Martin, and D. H. Ledbetter: Deletion 17q12 Is a Recurrent Copy Number Variant that Confers High Risk of Autism and Schizophrenia. American Journal of Human Genetics, 87(5), 618-630 (2010)

DOI: 10.1016/j.ajhg.2010.10.004

PMid:21055719 PMCid: PMC2978962

64. S. J. Sanders, A. G. Ercan-Sencicek, V. Hus, R. Luo, M. T. Murtha, D. Moreno-De-Luca, S. H. Chu, M. P. Moreau, A. R. Gupta, S. A. Thomson, C. E. Mason, K. Bilguvar, P. B. Celestino-Soper, M. Choi, E. L. Crawford, L. Davis, N. R. Wright, R. M. Dhodapkar, M. DiCola, N. M. DiLullo, T. V. Fernandez, V. Fielding-Singh, D. O. Fishman, S. Frahm, R. Garagaloyan, G. S. Goh, S. Kammela, L. Klei, J. K. Lowe, S. C. Lund, A. D. McGrew, K. A. Meyer, W. J. Moffat, J. D. Murdoch, B.
J. O'Roak, G. T. Ober, R. S. Pottenger, M. J. Raubeson, Y. Song, Q. Wang, B. L. Yaspan, T. W. Yu, I. R. Yurkiewicz, A. L. Beaudet, R. M. Cantor, M. Curland, D. E. Grice, M. Gunel, R. P. Lifton, S. M. Mane, D. M. Martin, C. A. Shaw, M. Sheldon, J. A. Tischfield, C. A. Walsh, E. M. Morrow, D.H. Ledbetter, E. Fombonne, C. Lord, C. L. Martin, A. I. Brooks, J. S. Sutcliffe, E. H. Jr Cook, D. Geschwind, K. Roeder, B. Devlin, and M. W. State: Multiple recurrent de novo CNVs, including duplications of the $7 q 11.23$ Williams syndrome region, are strongly associated with autism. Neuron, 70(5), 863-885 (2011)

DOI: 10.1016/j.neuron.2011.05.002

PMid:21658581 PMCid: PMC3939065

65. J. T. Glessner, K. Wang, G. Cai, O. Korvatska, C. E. Kim, S. Wood, H. Zhang, A. Estes, C. W. Brune, J. P. Bradfield, M. Imielinski, E. C. Frackelton, J. Reichert, E. L. Crawford, J. Munson, P. M. Sleiman, R. Chiavacci, K. Annaiah, K. Thomas, C. Hou, W. Glaberson, J. Flory, F. Otieno, M. Garris, L. Soorya, L. Klei, J. Piven, K. J. Meyer, E. Anagnostou, T. Sakurai, R. M. Game, D. S. Rudd, D. Zurawiecki, C. J. McDougle, L. K. Davis, J. Miller, D. J. Posey, S. Michaels, A. Kolevzon, J. M. Silverman, R. Bernier, S. E. Levy, R. T. Schultz, G. Dawson, T. Owley, W. M. McMahon, T. H. Wassink, J. A. Sweeney, J. I. Nurnberger, H. Coon, J. S. Sutcliffe, N. J. Minshew, S. F. Grant, M. Bucan, E. H. Cook, J. D. Buxbaum, B. Devlin, G. D. Schellenberg and H. Hakonarson: Autism genome-wide copy number variation reveals ubiquitin and neuronal genes. Nature, 459(7246), 569-73 (2009)

DOI: 10.1038/nature07953

PMid:19404257 PMCid: PMC2925224

66. J. Hu, J. Liao, M. Sathanoori, S. Kochmar, J. Sebastian, S. Yatsenko and U. Surti: CNTN6 copy number variations in 14 patients: a possible candidate gene for neurodevelopmental and neuropsychiatric disorders. Journal of Neurodevelopmental Disorders, 7(1), 1-9 (2015)

DOI: 10.1186/s11689-015-9122-9

PMid:26257835 PMCid: PMC4528395

67. A. J. Griswold, D. Ma, H. N. Cukier, L. D. Nations, M. A. Schmidt, R. H. Chung, J. M. Jaworski, D. Salyakina, I. Konidari, P. L. Whitehead, H. H. Wright, R. K. Abramson, S. M. Williams, R. Menon, E. R. Martin, J. L. 
Haines, J. R. Gilbert, M. L. Cuccaro and M. A. Pericak-Vance: Evaluation of copy number variations reveals novel candidate genes in autism spectrum disorder-associated pathways. Human molecular genetics, 21(15), 3513-23 (2012)

DOI: $10.1093 / \mathrm{hmg} / \mathrm{dds} 164$

PMid:22543975 PMCid: PMC3392110

68. S. Dong, M. F. Walker, N. J. Carriero, M. DiCola, A. J. Willsey, A. Y. Ye, Z. Waqar, L. E. Gonzalez, J. D. Overton, S. Frahm, J. F. Keaney, N. A. Teran, J. Dea, J. D. Mandell, V. Hus Bal, C. A. Sullivan, N. M. DiLullo, R. O. Khalil, J. Gockley, Z. Yuksel, S. M. Sertel, A. G. Ercan-Sencicek, A. R. Gupta, S. M. Mane, M. Sheldon, A. I. Brooks, K. Roeder, B. Devlin, M. W. State, L. Wei and S. J. Sanders: De novo insertions and deletions of predominantly paternal origin are associated with autism spectrum disorder. Cell Rep, 9(1), 16-23 (2014)

DOI: 10.1016/j.celrep.2014.08.068

PMid:25284784 PMCid: PMC4194132

69. C. Kanduri, K. Kantojarvi, P. M. Salo, R. Vanhala, G. Buck, C. Blancher, H. Lahdesmaki and I. Jarvela: The landscape of copy number variations in Finnish families with autism spectrum disorders. Autism Res, 9(1), 9-16 (2016)

DOI: 10.1002/aur.1502

PMid:26052927

70. I. lossifov, M. Ronemus, D. Levy, Z. Wang, I. Hakker, J. Rosenbaum, B. Yamrom, Y. H. Lee, G. Narzisi, A. Leotta, J. Kendall, E. Grabowska, B. Ma, S. Marks, L. Rodgers, A. Stepansky, J. Troge, P. Andrews, M. Bekritsky, K. Pradhan, E. Ghiban, M. Kramer, J. Parla, R. Demeter, L. L. Fulton, R. S. Fulton, V. J. Magrini, K. Ye, J. C. Darnell, R. B. Darnell, E. R. Mardis, R. K. Wilson, M. C. Schatz, W. R. McCombie and M. Wigler: De novo gene disruptions in children on the autistic spectrum. Neuron, 74(2), 285-99 (2012)

DOI: 10.1016/j.neuron.2012.04.009

PMid:22542183 PMCid: PMC3619976

71. W.J. Ma, M. Hashii, T. Munesue, K. Hayashi, K. Yagi, M. Yamagishi, H. Higashida and S. Yokoyama: Non-synonymous singlenucleotide variations of the human oxytocin receptor gene and autism spectrum disorders: a case-control study in a Japanese population and functional analysis. Mol Autism, 4(1),
$22(2013)$

DOI: 10.1186/2040-2392-4-22

PMid:23815867 PMCid: PMC3707786

72. S. J. Sanders, M. T. Murtha, A. R. Gupta, J. D. Murdoch, M. J. Raubeson, A. J. Willsey, A. G. Ercan-Sencicek, N. M. DiLullo, N. N. Parikshak, J. L. Stein, M. F. Walker, G. T. Ober, N. A. Teran, Y. Song, P. El-Fishawy, R. C. Murtha, M. Choi, J. D. Overton, R. D. Bjornson, N. J. Carriero, K. A. Meyer, K. Bilguvar, S. M. Mane, N. Sestan, R. P. Lifton, M. Gunel, K. Roeder, D. H. Geschwind, B. Devlin and M. W. State: De novo mutations revealed by whole-exome sequencing are strongly associated with autism. Nature, 485(7397), 237-41 (2012)

DOI: $10.1038 /$ nature10945

PMid:22495306 PMCid: PMC3667984

73. S. De Rubeis, X. He, A. P. Goldberg, C. S. Poultney, K. Samocha, A. E. Cicek, Y. Kou, L. Liu, M. Fromer, S. Walker, T. Singh, L. Klei, J. Kosmicki, S.-C. Fu, B. Aleksic, M. Biscaldi, P. F. Bolton, J. M. Brownfeld, J. Cai, N. J. Campbell, A. Carracedo, M. H. Chahrour, A. G. Chiocchetti, H. Coon, E. L. Crawford, L. Crooks, S. R. Curran, G. Dawson, E. Duketis, B. A. Fernandez, L. Gallagher, E. Geller, S. J. Guter, R. S. Hill, I. Ionita-Laza, P. J. Gonzalez, H. Kilpinen, S. M. Klauck, A. Kolevzon, I. Lee, J. Lei, T. Lehtimäki, C.-F. Lin, A. Ma'ayan, C. R. Marshall, A. L. Mclnnes, B. Neale, M. J. Owen, N. Ozaki, M. Parellada, J. R. Parr, S. Purcell, K. Puura, D. Rajagopalan, K. Rehnström, A. Reichenberg, A. Sabo, M. Sachse, S. J. Sanders, C. Schafer, M. Schulte-Rüther, D. Skuse, C. Stevens, P. Szatmari, K. Tammimies, O. Valladares, A. Voran, L.-S. Wang, L. A. Weiss, A. J. Willsey, T. W. Yu, R. K. C. Yuen, D. D. D. S. the, A. Homozygosity Mapping Collaborative for, U. K. Consortium, C. the Autism Sequencing, E. H. Cook, C. M. Freitag, M. Gill, C. M. Hultman, T. Lehner, A. Palotie, G. D. Schellenberg, P. Sklar, M. W. State, J. S. Sutcliffe, C. A. Walsh, S. W. Scherer, M. E. Zwick, J. C. Barrett, D. J. Cutler, K. Roeder, B. Devlin, M. J. Daly and J. D. Buxbaum: Synaptic, transcriptional, and chromatin genes disrupted in autism. Nature, 515(7526), 209-215 (2014)

DOI: $10.1038 /$ nature 13772

PMid:25363760 PMCid: PMC4402723

74. M. Pilorge, C. Fassier, H. Le Corronc, A. Potey, 
J. Bai, S. De Gois, E. Delaby, B. Assouline, V. Guinchat, F. Devillard, R. Delorme, G. Nygren, M. Rastam, J. C. Meier, S. Otani, H. Cheval, V. M. James, M. Topf, T. N. Dear, C. Gillberg, M. Leboyer, B. Giros, S. Gautron, J. Hazan, R. J. Harvey, P. Legendre and C. Betancur: Genetic and functional analyses demonstrate a role for abnormal glycinergic signaling in autism. Mol Psychiatry (2015)

75. J. Weissman, S. Naidu and H. T. Bjornsson: Abnormalities of the DNA methylation mark and its machinery: an emerging cause of neurologic dysfunction. Semin Neurol, 34(3), 249-257 (2014)

DOI: 10.1055/s-0034-1386763

PMid:25192503 PMCid: PMC4512289

76. M. Laplana, J. L. Royo, A. Aluja, R. López, D. Heine-Sunyer and J. Fibla: Absence of substantial copy number differences in a pair of monozygotic twins discordant for features of autism spectrum disorder. Case Rep Genet, 2014, 516529 (2014)

77. C. Helsmoortel, A. T. Vulto-van Silfhout, B. P. Coe, G. Vandeweyer, L. Rooms, J. van den Ende, J. H. Schuurs-Hoeijmakers, C. L. Marcelis, M. H. Willemsen, L. E. Vissers, H. G. Yntema, M. Bakshi, M. Wilson, K. T. Witherspoon, H. Malmgren, A. Nordgren, G. Anneren, M. Fichera, P. Bosco, C. Romano, B. B. de Vries, T. Kleefstra, R. F. Kooy, E. E. Eichler and N. Van der Aa: A SWI/SNFrelated autism syndrome caused by de novo mutations in ADNP. Nat Genet 46(4), 380-384 (2014)

DOI: 10.1038/ng.2899

PMid:24531329 PMCid: PMC3990853

78. A. M. D'Gama, S. Pochareddy, M. Li, S. S. Jamuar, R. E. Reiff, A. T. Lam, N. Sestan and C. A. Walsh: Targeted DNA Sequencing from Autism Spectrum Disorder Brains Implicates Multiple Genetic Mechanisms. Neuron, 88(5), 910-917 (2015)

DOI: 10.1016/j.neuron.2015.11.009

PMid:26637798

79. A. Adegbola, H. Gao, S. Sommer and M. Browning: A novel mutation in JARID1C/ SMCX in a patient with autism spectrum disorder (ASD). Am J Med Genet A 146a(4), 505-511 (2008)

80. S. Dong, M. F. Walker, N. J. Carriero, M. DiCola, A. J. Willsey, A. Y. Ye, Z. Waqar, L.
E. Gonzalez, J. D. Overton, S. Frahm, J. F. Keaney, N. A. Teran, J. Dea, J. D. Mandell, V. H. Bal, C. A. Sullivan, N. M. DiLullo, R. O. Khalil, J. Gockley, Z. Yuksel, S. M. Sertel, A. G. Ercan-Sencicek, A. R. Gupta, S. M. Mane, M. Sheldon, A. I. Brooks, K. Roeder, B. Devlin, M. W. State, L. Wei and S. J. Sanders: De novo insertions and deletions of predominantly paternal origin are associated with autism spectrum disorder. Cell reports, 9(1), 16-23 (2014)

DOI: 10.1016/j.celrep.2014.08.068

PMid:25284784 PMCid: PMC4194132

81. M. Mor, S. Nardone, D. S. Sams and E. Elliott: Hypomethylation of miR-142 promoter and upregulation of microRNAs that target the oxytocin receptor gene in the autism prefrontal cortex. Mol Autism, 6, 46 (2015)

82. S. G. Gregory, J. J. Connelly, A. J. Towers, J. Johnson, D. Biscocho, C. A. Markunas, C. Lintas, R. K. Abramson, H. H. Wright, P. Ellis, C. F. Langford, G. Worley, G. R. Delong, S. K. Murphy, M. L. Cuccaro, A. Persico and M. A. Pericak-Vance: Genomic and epigenetic evidence for oxytocin receptor deficiency in autism. BMC Medicine, 7(1), 1-13 (2009)

DOI: $10.1186 / 1741-7015-7-62$

PMid:19845972 PMCid: PMC2774338

83. A. Baccarelli and V. Bollati: Epigenetics and environmental chemicals. Current opinion in pediatrics, 21(2), 243-51 (2009)

DOI: 10.1097/MOP.0b013e32832925cc

PMid:19663042 PMCid: PMC3035853

84. H. O. Atladottir, P. Thorsen, L. Ostergaard, D. E. Schendel, S. Lemcke, M. Abdallah and E. T. Parner: Maternal infection requiring hospitalization during pregnancy and autism spectrum disorders. Journal of autism and developmental disorders, 40(12), 1423-30 (2010)

DOI: 10.1007/s10803-010-1006-y

PMid:20414802

85. A. S. Dickerson, M. H. Rahbar, I. Han, A. V. Bakian, D. A. Bilder, R. A. Harrington, S. Pettygrove, M. Durkin, R. S. Kirby, M. S. Wingate, L. H. Tian, W. M. Zahorodny, D. A. Pearson, L. A. Moye, $3^{\text {rd }}$ and J. Baio: Autism spectrum disorder prevalence and proximity to industrial facilities releasing arsenic, lead or mercury. Sci Total Environ, 536, 245-51 (2015) DOI: 10.1016/j.scitotenv.2015.07.024 
PMid:26218563 PMCid: PMC4721249

86. X. Ren, C. M. McHale, C. F. Skibola, A. H. Smith, M. T. Smith and L. Zhang: An emerging role for epigenetic dysregulation in arsenic toxicity and carcinogenesis. Environ Health Perspect, 119(1), 11-9 (2011)

DOI: 10.1289/ehp.1002114

PMid:20682481 PMCid: PMC3018488

87. Y. Al-Farsi, M. Waly, M. Al-Sharbati, M. Al-Shafaee, O. Al-Farsi, M. Al-Khaduri, I. Gupta, A. Ouhtit, S. Al-Adawi, M. Al-Said and R. Deth: Levels of Heavy Metals and Essential Minerals in Hair Samples of Children with Autism in Oman: a Case-Control Study. Biological Trace Element Research, 151(2), 181-186 (2013)

DOI: $10.1007 / \mathrm{s} 12011-012-9553-z$

PMid:23188679

88. N. W. Hodgson, M. I. Waly, Y. M. Al-Farsi, M. M. Al-Sharbati, O. Al-Farsi, A. Ali, A. Ouhtit, T. Zang, Z. S. Zhou and R. C. Deth: Decreased glutathione and elevated hair mercury levels are associated with nutritional deficiencybased autism in Oman. Experimental Biology and Medicine, 239(6), 697-706 (2014)

DOI: $10.1177 / 1535370214527900$

PMid:24676906

89. P. Surén, C. Roth, M. Bresnahan, M. Haugen, M. Hornig, D. Hirtz, K. K. Lie, W. I. Lipkin, P. Magnus, T. Reichborn-Kjennerud, $\mathrm{S}$. Schjølberg, G. Davey Smith, A. S. Øyen, E. Susser and C. Stoltenberg: Association between maternal use of folic acid supplements and risk of autism spectrum disorders in children. JAMA, 309(6), 570-7 (2013)

DOI: 10.1001/jama.2012.155925

PMid:23403681 PMCid: PMC3908544

90. D. A. Rossignol: Novel and emerging treatments for autism spectrum disorders: a systematic review. Ann Clin Psychiatry, 21(4), 213-36 (2009)

91. L. A. Vismara and S. J. Rogers: Behavioral treatments in autism spectrum disorder: what do we know? Annu Rev Clin Psychol, 6, 447-68 (2010)

92. L. F. Marti: Dietary interventions in children with autism spectrum disorders - an updated review of the research evidence. Curr Clin Pharmacol, 9(4), 335-49 (2014)

DOI: $10.2174 / 15748847113086660074$

PMid:24050740
93. P. Whiteley, P. Shattock, A. M. Knivsberg, A. Seim, K. L. Reichelt, L. Todd, K. Carr and M. Hooper: Gluten- and casein-free dietary intervention for autism spectrum conditions. Front Hum Neurosci, 6, 344 (2012)

94. A. Kawicka and B. Regulska-llow: How nutritional status, diet and dietary supplements can affect autism. A review. Rocz Panstw Zakl Hig, 64(1), 1-12 (2013)

95. Y. M. Al-Farsi, M. I. Waly, R. C. Deth, M. M. Al-Sharbati, M. Al-Shafaee, O. Al-Farsi, M. M. Al-Khaduri, I. Gupta, A. Ali, M. Al-Khalili, S. Al-Adawi, N. W. Hodgson and A. Ouhtit: Low folate and vitamin B12 nourishment is common in Omani children with newly diagnosed autism. Nutrition, 29(3), 537-541 (2013)

DOI: 10.1016/j.nut.2012.09.014

PMid:23287069

96. T. Gaugler, L. Klei, S. J. Sanders, C. A. Bodea, A. P. Goldberg, A. B. Lee, M. Mahajan, D. Manaa, Y. Pawitan, J. Reichert, S. Ripke, S. Sandin, P. Sklar, O. Svantesson, A. Reichenberg, C. M. Hultman, B. Devlin, K. Roeder and J. D. Buxbaum: Most genetic risk for autism resides with common variation. Nature genetics, 46(8), 881-885 (2014)

DOI: 10.1038/ng.3039

PMid:25038753 PMCid: PMC4137411

97. R. Anney, L. Klei, D. Pinto, J. Almeida, E. Bacchelli, G. Baird, N. Bolshakova, S. Bolte, P. F. Bolton, T. Bourgeron, S. Brennan, J. Brian, J. Casey, J. Conroy, C. Correia, C. Corsello, E. L. Crawford, M. de Jonge, R. Delorme, E. Duketis, F. Duque, A. Estes, P. Farrar, B. A. Fernandez, S. E. Folstein, E. Fombonne, J. Gilbert, C. Gillberg, J. T. Glessner, A. Green, J. Green, S. J. Guter, E. A. Heron, R. Holt, J. L. Howe, G. Hughes, V. Hus, R. Igliozzi, S. Jacob, G. P. Kenny, C. Kim, A. Kolevzon, V. Kustanovich, C. M. Lajonchere, J. A. Lamb, M. Law-Smith, M. Leboyer, A. Le Couteur, B. L. Leventhal, X. Q. Liu, F. Lombard, C. Lord, L. Lotspeich, S. C. Lund, T. R. Magalhaes, C. Mantoulan, C. J. McDougle, N. M. Melhem, A. Merikangas, N. J. Minshew, G. K. Mirza, J. Munson, C. Noakes, G. Nygren, K. Papanikolaou, A. T. Pagnamenta, B. Parrini, T. Paton, A. Pickles, D. J. Posey, F. Poustka, J. Ragoussis, R. Regan, W. Roberts, K. Roeder, B. Roge, M. L. Rutter, S. Schlitt, N. Shah, V. C. Sheffield, L. Soorya, I. Sousa, V. Stoppioni, N. Sykes, R. Tancredi, A. 
P. Thompson, S. Thomson, A. Tryfon, J. Tsiantis, H. Van Engeland, J. B. Vincent, F. Volkmar, J. A. Vorstman, S. Wallace, K. Wing, K. Wittemeyer, S. Wood, D. Zurawiecki, L. Zwaigenbaum, A. J. Bailey, A. Battaglia, R. M. Cantor, H. Coon, M. L. Cuccaro, G. Dawson, S. Ennis, C. M. Freitag, D. H. Geschwind, J. L. Haines, S. M. Klauck, W. M. McMahon, E. Maestrini, J. Miller, A. P. Monaco, S. F. Nelson, J. I. Nurnberger, Jr., G. Oliveira, J. R. Parr, M. A. Pericak-Vance, J. Piven, G. D. Schellenberg, S. W. Scherer, A. M. Vicente, T. H. Wassink, E. M. Wijsman, C. Betancur, J. D. Buxbaum, E. H. Cook, L. Gallagher, M. Gill, J. Hallmayer, A. D. Paterson, J. S. Sutcliffe, P. Szatmari, V. J. Vieland, H. Hakonarson and B. Devlin: Individual common variants exert weak effects on the risk for autism spectrum disorderspi. Human molecular genetics, 21(21), 4781-92 (2012)

DOI: $10.1093 / \mathrm{hmg} / \mathrm{dds} 301$

PMid:22843504 PMCid: PMC3471395

98. Elaine T. Lim, S. Raychaudhuri, Stephan J. Sanders, C. Stevens, A. Sabo, Daniel G. MacArthur, Benjamin M. Neale, A. Kirby, Douglas M. Ruderfer, M. Fromer, M. Lek, L. Liu, J. Flannick, S. Ripke, U. Nagaswamy, D. Muzny, Jeffrey G. Reid, A. Hawes, I. Newsham, Y. Wu, L. Lewis, H. Dinh, S. Gross, L.-S. Wang, C.-F. Lin, O. Valladares, Stacey B. Gabriel, M. dePristo, David M. Altshuler, Shaun M. Purcell, Matthew W. State, E. Boerwinkle, Joseph D. Buxbaum, Edwin H. Cook, Richard A. Gibbs, Gerard D. Schellenberg, James S. Sutcliffe, B. Devlin, K. Roeder and Mark J. Daly: Rare Complete Knockouts in Humans: Population Distribution and Significant Role in Autism Spectrum Disorders. Neuron, 77(2), 235-242 (2013)

DOI: 10.1016/j.neuron.2012.12.029

PMid:23352160 PMCid:PMC3613849

99. N. Navot, A. G. Jorgenson, A. Vander Stoep, K. Toth and S. J. Webb: Family planning and family vision in mothers after diagnosis of a child with autism spectrum disorder. Autism (2015)

100. H. Yamasue: Promising evidence and remaining issues regarding the clinical application of oxytocin in autism spectrum disorders. Psychiatry Clin Neurosci (2015)

101. L. G. Rabaneda, E. Robles-Lanuza, J. L. Nieto-Gonzalez and F. G. Scholl: Neurexin dysfunction in adult neurons results in autistic-like behavior in mice. Cell Rep, 8(2), 338-46 (2014)

DOI: 10.1016/j.celrep.2014.06.022

PMid:25017069

Key Words: Autism Spectrum Disorder, Genetics, Genomics, Review

Send correspondence to: Allal Ouhtit, Department of Biological and Environmental Sciences, College of Art and Science, Qatar University, P.O. Box 2713 Qatar, Tel: 974 44037572, Fax: 974-4403-4531, E-mail: aouhtit@qu.edu.qa 